\title{
Essential Oil Profile of Wild and Cultivated Accession of Cymbopogon schoenanthus (L.) from Uttarakhand Region
}

\section{Harish Chandra Andola ${ }^{1^{\star}}$ and Alok Maithani ${ }^{2}$}

${ }^{1}$ School of Environment and Natural Resource Management, Doon University, Dehradun, Uttarakhand, India

${ }^{2}$ Department of Applied Chemistry, Sardar Bhagwan Singh PG Institute, Balawala, Dehradun, Uttarakhand, India

\begin{abstract}
The chemical composition of the essential oils of Cymbopogon schoenanthus (L.) was investigated by GC and GC/MS study. Cis-sabinene hydrate was found as the major component which varies from $30.1-31.6 \%$ in wild and cultivated plants whereas trans-sabinene was found to be second highest constituent which was $17.1 \%$ in wild sample and $14.5 \%$ in cultivated oil sample. Results reveals that chemical composition of Cymbopogon schoenanthus wild and cultivated oil has similar composition but both of them varied quantitatively especially in case of cis-piperitol. Data set indicates that species cultivated in tarai and plain region of Uttarakhand can be used for trapping sabinene hydrate which is present in very good amount in both the samples.
\end{abstract}

Keywords: Cymbopogon schoenanthus (L.); Wild; Cultivated; Essential oil; GC; GC/MS

\section{Introduction}

The genus of Cymbopogon species are distributed worldwide through countries which are located within or around the tropical and subtropical bands. Most of the species of this genus are found in their motherland (Asia) [1]. Several species of the genus are known for economically important chemicals such as essential oil obtained from a number of species used as such in perfumery and highly valued novel molecules are used in flavoring and pharmaceutical industry. Due to its pleasant aroma and taste, it is also used to prepare aromatic "tea" that is much appreciated and largely consumed in North Africa [2]. Besides the culinary use of herb, it is also a popular folk medicine [3]. In the South of Tunisia, this plant is used for the treatment of rheumatism and to diminish fever. The plant is particularly appreciated for its medicinal action in North Africa and it is also used for the anorexia. The infusions are taken as a diuretic, it cures intestinal troubles and, in the form of decoction, it acts against food poisoning and also helps in the digestion [4]. Some of the Cymbopogon species are cultivated in commercials scale like $C$. nardus, $C$. witerianus, $C$. martini and $C$. flexuosus [5], it was found that no systematic study has been reported so far in C. schoenanthus cultivated in Doon valley compared with its original accession.

\section{Materials and Methods \\ Collection of plant material}

Aerial parts of C. schoenanthus were collected from Raiwala near Haridwar Uttarakhand, North Himalaya region in the month of July 2013 and planted in University demonstration site. Voucher specimen has been kept in the herbarium of Doon University dually by Botanical Survey of India, Dehradun, Dr. DK Shrivatava for further reference.

\section{Extraction of oil}

Shade dry aerial parts were subjected to hydro distillation in Clevenger apparatus for 6 hours to extract oil; obtained oil was dried over anhydrous sodium sulphate and stored in a refrigerator till further analysis. The essential oil content was determined as percentage on shade dry weight basis as average of three independent extractions to minimize error. The combined oil was used for further analysis.

\section{GC}

Analysis by GC was performed by using Agilent (model 6890) gas chromatograph equipped with a FID detector and a HP-5 fused silica column $(30 \mathrm{~m} \times 0.32 \mathrm{~mm} \times 0.25 \mu \mathrm{m}$ film thickness). Nitrogen was used as a carrier gas during analysis. The injector and detector temperature were maintained at $210^{\circ} \mathrm{C}$ and $230^{\circ} \mathrm{C}$ respectively. The column oven temperature was programmed from $60^{\circ} \mathrm{C}$ to $220^{\circ} \mathrm{C}$ with an increase in rate of $3^{\circ} \mathrm{C} / \mathrm{min}$.

\section{GC/MS}

Analysis was carried out on a Perkin Elmer mass spectrometer coupled to a Perkin Elmer Claurus 500 gas chromatograph with a $60 \mathrm{~m}$ $\times 0.32 \mathrm{~mm} \times 0.25 \mu \mathrm{m}$ film thickness column of Rtx-5. Helium was used as the carrier gas (flow rate $1 \mathrm{ml} / \mathrm{min}$ ). The mass range was scanned from 40-600 Daltons. The oven temperature programme range was $60^{\circ} \mathrm{C}$ to $220^{\circ} \mathrm{C}$ with an increase in rate of $3^{\circ} \mathrm{C} / \mathrm{min}$. Other conditions were the same as described in GC.

\section{Identification of components}

The identity of the constituents of the oil was established on the basis of GC retention indices, by comparing their $70 \mathrm{eV}$ mass spectra with those reported in literature [6] and by computer matching with NIST and Wiley libraries, as well as. Where possible, co-injection was done with authentic standard compounds available in our laboratory.

\section{Results and Discussion}

The essential oil content in cultivated sample was found to be higher $(2.05 \%)$ than that in wild sample $(1.80 \%)$. The chemical composition of both the samples is presented in Table 1 . A total of 10 components were identified in both the samples where proportion

*Corresponding author: Harish Chandra Andola, School of Environment and Natural Resource Management, Doon University, Dehradun, Uttarakhand, India, Tel: +919412375416; E-mail: andolah@rediffmail.com

Received January 18, 2018; Accepted January 22, 2018; Published January 27, 2018

Citation: Andola HC, Maithani A (2018) Essential Oil Profile of Wild and Cultivated Accession of Cymbopogon schoenanthus (L) from Uttarakhand Region. Med Chem (Los Angeles) 8: 008-009. doi: 10.4172/2161-0444.10489

Copyright: (c) 2018 Andola HC, et al. This is an open-access article distributed under the terms of the Creative Commons Attribution License, which permits unrestricted use, distribution, and reproduction in any medium, provided the original author and source are credited. 


\begin{tabular}{|c|c|c|c|}
\hline \multirow{2}{*}{ RI } & Components & $\begin{array}{c}\text { Raiwala } \\
\text { (Wild) }\end{array}$ & $\begin{array}{c}\text { Doon University, Dehradun } \\
\text { (Cultivated) }\end{array}$ \\
\cline { 3 - 4 } & & $\mathbf{( \% )}$ & $\mathbf{( \% )}$ \\
\hline p-cymene & 1025 & 4.5 & 4.3 \\
\hline a-terpinolene & 1081 & 11 & 7.9 \\
\hline Limonene & 1029 & 3.2 & 3.8 \\
\hline $\begin{array}{c}\text { Cis-sabinene } \\
\text { hydrate }\end{array}$ & 1070 & 30.1 & 31.6 \\
\hline $\begin{array}{c}\text { Trans-sabinene } \\
\text { hydrate }\end{array}$ & 1098 & 17.1 & 14.5 \\
\hline a terpineol & 1189 & 1.2 & 1.1 \\
\hline Piperitone & 1253 & 2.7 & 3.7 \\
\hline Cis-piperitol & 1196 & 9.6 & 18.5 \\
\hline Trans-piperitol & 1208 & 8.5 & 7.2 \\
\hline Eucarvone & - & 1 & 1.7 \\
\hline Total Identified & & $\mathbf{8 8 . 9}$ & $\mathbf{9 4 . 3}$ \\
\hline
\end{tabular}

$\mathrm{RI}=$ Retention indices on HP -5 capillary column; Percentage of components (Average of three analyzed replicates).

Table 1: Essential oil composition of Cymbopogon schoenanthus.

of monoterpenes was higher than that of sesquiterpenes. Results of chemical identification advocates three monoterpenes as principal components whereas highest concentration was shared by cis-sabinene followed by trans isomer and cis-piperitol. The concentration of major component that is, cis-sabinene hydrate was found to be 30.1 and $31.6 \%$ while second major component was trans-sabinene which was found to be $17.1 \%$ in wild sample and $14.5 \%$ in cultivated sample. Cis-piperitol was detected as the third major component in cultivated sample (18.5\%), but its concentration was found to be just half in wild sample. Other components were $\alpha$-terpinolene, piperitone and limonene. Earlier reports of samples originated from Burkina reported piperitone $(42.0 \%)$ and elemol as major components [7]. Whereas Brazil oil sample reported geraniol (62.5\%) and geranial (12.5\%) as major components [8]. Main chemical compound of Cymbopogon scheonanthus is piperitone $(42.0 \%)$, from Burkina $[9,10]$. In three different locations in Tunisia oil, major components were limonene (10.5-27.3\%), $\beta$-phellandrene (8.2-16.3\%), $\alpha$-terpinene $(4.3-21.2 \%)$ and $\alpha$-terpineol (6.8-11.0\%) [5]. However, samples from Indian Thar Desert reported 2-undecanone (14.68\%) and limonene (19.54\%) as major components [11]. These reports disagree with our present investigation. This variation is due to difference genetic make up, microclimatic and environmental condition of the places where the species are grown. It is further reported that sabinene hydrate and its acetate are responsible for the spicy flavor [12]. It is present in good amount in our investigated oil. cis-piperitol, a-terpinolene, and limonene are used in various industrial applications. C. schoenanthus essential oil is active against termites [13] and against the brushed Callosobruchus maculatus, which is a major pest of stored grains [10]. C. schoenanthus essential oil could be an interesting candidate for its application in gastrointestinal nematodes control blend with other aroma chemicals. Therefore, oil of C. schoenanthus cultivated in lower like foothills of the region and plain topography of Uttarakhand state could be a better option for flavor, pharmaceutical and aromatic industry for trapping its potential components which are desired for industry.

\section{Acknowledgments} of study.

The authors thank colleagues of SENR for the support and help during course

\section{References}

1. Khanuja SPS, Shasany AK, Pawar A, Lal RK, Darokar MP, et al. (2005) Essential oil constituents and RAPD markers to establish species relationship in Cymbopogon Spreng (Poaceae). Biochem Syst Ecol 33: 171-186.

2. IUCN (2005) A guide to medicinal plants in North Africa. p: 256.

3. Pline LA (1965) Histoire Naturelle. Livre XX, XXII. Paris Ed. D Emile Litter, pp: 1848-1850.

4. Khadri A, Serralheiro MLM, Nogueira JMF, Neffati M, Smiti S, et al. (2008) Antioxidant and antiacetylcholinesterase activities of essential oils from Cymbopogon schoenanthus L. Spreng determination. Food Chem 109: 630-637.

5. Heiba HI, Rizk AM (1986) Constituents of Cymbopogon species. Qatar University Science Bulletin 6: 53-75.

6. Adams RP (2007) Identification of essential oil components by gas chromatography/ mass spectrometry: Carol Stream. Allured Publishing, IL, USA.

7. Yentema O, Alioune O, Dorosso SA (2007) Chemical composition and physical characteristic of Essential oil of Cymbopogon schoenanthus (L.) Spreng of Burkina Faso. Journal of Applied Science 7: 503-506.

8. Katiki LM, Chagas ACS, Bizzo HR, Ferreira JFS, Amarante AFT (2011) Anthelmintic activity of Cymbopogon martinii, Cymbopogon schoenanthus and Mentha piperita essential oils evaluated in four different in vitro tests. Vet Parasitol 183: 103-108

9. Ketoh G (2006) Comparative effects of Cymbopogon schoenanthus essentia oil and piperitone on Callosobruchus maculatus development. Fitoterapia 77: 506-510.

10. Shahi AK, Tava A (1993) Essential oil composition of three Cymbopogon species of Indian Thar Desert. J Essent Oil Res 5: 639-643.

11. Novak J, Langbehn J, Pank F, Franz CM (2002) Essential oil compounds in a historical sample of marjoram (Origanum majorana L., Lamiaceae). Flav Fragr J 17: 175-180.

12. Dubey NK, Shukla R, Kumar A, Singh P, Prakash B (2010) Prospects of botanical pesticides in sustainable Agriculture. Curr Sci 98: 479.

13. Koba K, Poutouli PW, Nenonene YA, Songai MS (2007) Chemical composition and anti-termite activity of three tropical essential oils against termite species Trinervitermes geminatus. Sci Techno 5: 39-46. 